\title{
Pengaruh Adversity Quotient terhadap Prestasi Akademik Mahasiswa Angkatan 2013 Fakultas Psikologi UIN SGD Bandung
}

\author{
Tesa N. Huda, Agus Mulyana \\ UIN Sunan Gunung Djati Bandung, Jl. A.H. Nasution No. 105 Bandung. \\ e-mail: tesanurulhuda@gmail.com
}

\begin{abstract}
The purpose of this research is to know how significant is the influence of adversity quotient to academic achievement. This research used correlational method with causality type. Respondents of the study were 147 students of Faculty of Psychology UIN SGD Bandung year 2013. The samples were 109 people, selected by simple random sampling technique. AQ measured by a Quick Take Adversity Response Profile (ARP) scale that is modified for educational settings. This study used simple regression analysis. Based on data processing using SPSS $20^{\text {th }}$ version, it was obtained sig value $(0.029)<\alpha(0.05)$. This value shows that $H_{0}$ is rejected, so there is a significant adversity quotient influence to academic achievement. Coefficient of determination equal to 0,044, showing influence of $A Q$ to academic achievement is $4.4 \%$. Therefore $A Q$ is one of the low factor that affect academic achievement.
\end{abstract}

Keywords: adversity quotient, academic achievement, GPA, ARP quick take

\begin{abstract}
Abstrak
Tujuan dari penelitian ini adalah untuk mengetahui seberapa besar pengaruh adversity quotient terhadap prestasi akademik. Penelitian ini menggunakan metode korelasional dengan tipe kausalitas. Subjek penelitian berjumlah 147 mahasiswa Fakultas Psikologi UIN SGD Bandung angkatan 2013. Jumlah sampel penelitian sebanyak 109 orang, dipilih dengan teknik simple random sampling. AQ diukur dengan menggunakan skala Adversity Response Profile (ARP) Quick Take yang dimodifikasi untuk setting pendidikan. Analisis statistik yang digunakan adalah analisis regresi sederhana. Berdasarkan pengolahan data dengan menggunakan SPSS versi 20, diperoleh nilai signifikansi $(0.029)<\alpha(0.05)$. Hal ini menunjukkan bahwa $\mathrm{H}_{0}$ ditolak, sehingga terdapat pengaruh signifikan adversity quotient terhadap prestasi akademik. Koefisien determinasi sebesar 0.044, menunjukkan pengaruh AQ terhadap prestasi akademik sebesar $4.4 \%$. Sehingga AQ termasuk pada faktor yang rendah dalam memengaruhi prestasi akademik.
\end{abstract}

Kata Kunci: adversity quotient, prestasi akademik, IPK, ARP quick take

\section{Pendahuluan}

Pendidikan bisa didapatkan dari mana saja, dari siapa saja, dan dalam keadaan apa saja, baik itu secara formal, informal, maupun nonformal. Pendidikan secara formal dilakukan di suatu instansi pendidikan seperti di Sekolah Dasar, Sekolah Menengah Pertama, maupun Sekolah Menengah Atas. Secara informal, pendidikan dapat ditempuh dengan jalan seperti mengikuti kursus-kursus, privat, dan lain-lain yang sejenisnya. Sedangkan secara nonformal, pembelajaran didapatkan dari lingkungan, baik itu lingkungan keluarga maupun lingkungan sosial yang lebih luas.
Sebagai negara hukum, Indonesia mengatur hak setiap warga negara untuk mengenyam bangku pendidikan pada UU nomor 20 tahun 2003. Bahkan mulai Juni 2015 pemerintah sudah mulai mencanangkan wajib belajar 12 tahun. Maksudnya, setiap warga negara wajib mengikuti pendidikan formal selama 12 tahun, dalam arti wajib mendapatkan pendidikan formal sampai jenjang Sekolah Menengah Atas (SMA).

Setelah melewati proses pendidikan formal selama 12 tahun mulai dari Sekolah Dasar sampai Sekolah Menengah Atas, banyak siswa yang mulai memikirkan 
untuk mencari pekerjaan. Meski begitu, tidak sedikit pula siswa yang memutuskan untuk melanjutkan pendidikannya ke jenjang perguruan tinggi.

Peserta didik yang terdaftar di perguruan tinggi disebut mahasiswa. Makna mahasiswa tidak hanya sekedar status administratif saja. Mahasiswa memiliki tanggung jawab yang sangat besar, karena masyarakat luas banyak yang menggantungkan harapan besar pada mereka. Mahasiswa adalah salah satu komponen dalam dunia pendidikan yang diharapkan menjadi seorang yang dapat memberikan solusi bagi permasalahan yang dihadapi oleh suatu masyarakat bangsa di berbagai belahan dunia.

Chakim (2012) menyebutkan peran dan fungsi yang sangat penting bagi mahasiwa adalah pertama, peranan moral. Mahasiswa harus memiliki tanggung jawab moral sesuai dengan norma yang berlaku di masyarakat, walaupun kehidupan di kampus memungkinkan mereka untuk bertindak sesuai apa yang mereka inginkan.

Kedua adalah peranan sosial. Mahasiswa tidak bisa hidup sendiri, karena mereka adalah makhluk sosial, manfaat yang dicarinya pun harus berguna untuk kehidupan sosialnya juga, tidak hanya untuk individu.

Ketiga adalah peranan intelektual. Fungsi dasar mahasiswa adalah bergelut dengan ilmu pengetahuan. Pada akhirnya mereka akan menggunakan intelektualitasnya itu untuk 'mengabdi' pada masyarakat.

Berbagai hal ditunjukkan setiap mahasiswa dengan cara berbeda dalam menyikapi fungsi dasar ini. Beberapa mahasiswa berjalan sesuai dengan fungsi dasar mereka, sehingga prestasi akademik yang mereka raih dapat dikatakan sangat memuaskan. Beberapa yang lain justru 'menyimpang' dan hal ini berdampak pada buruknya prestasi yang diraih.

Prestasi yang diraih biasanya akan sejalan dengan usaha yang dilakukan. Berdasarkan hasil observasi yang dilakukan di Fakultas Psikologi UIN Sunan Gunung Djati Bandung pada semester genap 2014/2015, ditemukan bahwa beberapa mahasiswa memang mendapatkan prestasi sesuai dengan usahanya. Tetapi tidak sedikit mahasiswa yang mendapatkan prestasinya justru berbanding terbalik dengan usaha yang telah dilakukannya.

Usaha yang dilakukan mahasiswa antara lain mengerjakan tugas yang diberikan dosen sebaik mungkin dan selesai pada waktu yang ditentukan. Selain itu mahasiswa terlihat melakukan usahanya yaitu dengan belajar lebih giat lagi saat akan ujian, bisa juga mahasiswa dikatakan sudah melakukan usaha saat mengulang materi yang diperoleh di kelas.

Mahasiswa yang mendapatkan hasil tidak sesuai dengan usaha yang dilakukannya ini dapat dikelompokkan menjadi dua kategori. Kelompok pertama, beberapa mahasiswa yang usahanya sudah sangat tinggi seperti mengerjakan tugas sebaik mungkin dan tidak melebihi deadline yang ditentukan, memperhatikan dosen saat perkuliahan berlangsung, lalu belajar dengan giat saat akan memasuki masa ujian, tetapi prestasi yang diraihnya masih tetap rendah.

Kelompok kedua yaitu para mahasiswa yang usahanya tidak sekeras mahasiswa di kelompok yang pertama, tetapi prestasinya baik, bahkan beberapa melebihi prestasi orang-orang dengan usaha yang sangat tinggi.

Dari 3 angkatan yang masih aktif melaksanakan perkuliahan di Fakultas Psikologi UIN Sunan Gunung Djati Bandung, angkatan 2013 memiliki rata-rata prestasi akademik yang paling tinggi jika dibandingkan dengan 2 angkatan lainnya, yaitu angkatan 2014 dan 2012.

Berdasarkan informasi yang didapatkan dari pihak terkait, diketahui total mahasiswa yang aktif sampai semester 4 pada angkatan 2013, lebih dari 50\% mahasiswa pada angkatan tersebut memiliki IPK yang lebih dari 3,00. Ratarata IPK dari semua mahasiswa aktif juga 
sudah sangat baik, karena hampir mendekati 3,00.

Menurut hasil wawancara yang dilakukan pada kurang lebih 10 orang mahasiswa angkatan 2013 (pada bulan April 2015), dapat ditarik kesimpulan bahwa mahasiswa dengan usaha yang sangat keras mendapatkan prestasi akademik yang sangat baik. Beberapa mahasiswa lain berusaha dengan cukup keras namun hasil yang didapatkan kurang sesuai. Sebagian mahasiswa justru merasa bahwa prestasi akademik yang selama ini mereka dapatkan lebih tinggi dari pada usaha yang mereka lakukan.

Para mahasiswa ini merasa bahwa usaha dalam melaksanakan perkuliahan ini sudah sesuai dengan tugas dan kewajiban yang seharusnya dilakukan, misalnya mengerjakan tugas, mengikuti perkuliahan dan ujian yang ada. Pada akhir semester para mahasiswa di kelompok ini mendapatkan prestasi akademik yang baik, padahal mereka berpikir hal tersebut terlalu bagus untuk usaha mereka yang tergolong biasa saja.

Membahas prestasi tentu tidak akan terlepas dari pembahasan mengenai kecerdasan yang dimiliki seseorang. Namun berhasil atau tidaknya seseorang dalam meraih prestasinya tidak hanya bergantung pada kecerdasannya saja.

Hal tersebut sejalan dengan Stoltz (2000) yang menyatakan bahwa kesuksesan seseorang bukan hanya terletak pada kecerdasan intelegensinya (IQ) atau pada kecerdasan emosinya (EQ) saja. Setelah melakukan penelitian, Stoltz menemukan faktor penentu kesuksesan seseorang salah satunya adalah daya usaha yang dimiliki orang itu atau biasa disebut dengan adversity quotient (AQ).

Menurut Stoltz (2000) AQ memberi informasi seberapa jauh seseorang bertahan dalam menghadapi kesulitan dan bagaimana kemampuannya dalam mengatasi kesulitan tersebut. AQ juga memprediksikan siapa yang mampu mengatasi kesulitan dan siapa yang akan hancur, siapa yang bertahan dan siapa yang menyerah, serta siapa yang akan melampaui harapan, dan siapa yang akan gagal.

Dibandingkan dengan fenomena yang terjadi pada mahasiswa angkatan 2013 di Fakultas Psikologi UIN SGD Bandung, idealnya jika tingkat $A Q$ yang dimiliki mahasiswa rendah, maka prestasi yang diraihnya pun rendah. Begitu pula sebaliknya, jika AQ mahasiswa tinggi, maka prestasinya pun tinggi.

\section{Adversity Quotient}

Adversity quotient (AQ) adalah suatu teori yang dicetuskan oleh Paul G. Stoltz, Ph.D, seorang President of PEAK Learning Incorporated yang meraih gelar doktor dalam bidang komunikasi dan pengembangan organisasi. Stoltz juga telah menjadi konsultan dan pemimpin dalam bidang pemikiran untuk berbagai macam organisasi di seluruh dunia.

Konsep IQ (intelligence quotient) telah lama dianggap sebagai penentu kesuksesan, namun ternyata beberapa orang dengan IQ tinggi tidak sedikit yang mengalami kegagalan. Setelah konsep IQ terkenal, Daniel Goleman memperkenalkan konsep baru mengenai kecerdasan, yaitu EQ (emotional quotient).

Menurut Stoltz (2000) IQ dan EQ tidak cukup untuk memprediksi kesuksesan seseorang, hal ini didukung setelah dilakukan riset selama 19 tahun dan penerapannya selama 10 tahun. Suksesnya pekerjaan dan hidup seseorang terutama ditentukan oleh adversity quotient (AQ).

Menurut Stoltz (2005) adversity quotient adalah suatu kemampuan untuk mengubah hambatan menjadi peluang keberhasilan mencapai tujuan. AQ mengungkap seberapa jauh seseorang mampu bertahan menghadapi kesulitan yang dialaminya. AQ juga mengungkap bagaimana kemampuan seseorang untuk mengatasi kesulitan tersebut. AQ memprediksi siapa yang mampu dan siapa yang tidak mampu dalam mengatasi kesulitan. 
AQ juga memprediksi siapa yang akan gagal dan siapa yang akan melampaui harapan-harapan atas kinerja dan potensinya. AQ juga memprediksi siapa yang akan menyerah ataupun bertahan (Stoltz, 2000).

Stoltz (2000: 9) mengungkapkan bahwa AQ mempunyai tiga bentuk, yaitu (1) AQ adalah suatu kerangka kerja konseptual yang baru untuk memahami dan meningkatkan semua segi kesuksesan. (2) AQ adalah suatu ukuran untuk mengetahui respon seseorang terhadap kesulitan. (3) AQ adalah serangkaian peralatan yang memiliki dasar ilmiah untuk memperbaiki respon seseorang terhadap kesulitan.

AQ dapat membantu individu dalam memperkuat kemampuan dan ketekunan mereka dalam menghadapi tantangan atau kesulitan hidup dengan tetap berpegang pada prinsip dan impian mereka tanpa mempedulikan yang terjadi (Stoltz, 2000: 12).

Menurut Stoltz (2000) AQ memengaruhi, bahkan bisa menentukan daya saing, produktivitas seseorang, kreativitas, motivasi, bagaimana seseorang mengambil resiko, dan bagaimana melakukan perbaikan pada masa yang akan datang. AQ juga bisa memprediksi ketekunan, daya belajar dari suatu peristiwa, bagaimana merangkul perubahan yang ada, keuletan, stress dan tekanan yang dialami, serta kemunduran dirinya.

Stoltz (2000) menganalogikan tipe-tipe AQ dengan para pendaki, karena menurutnya manusia dilahirkan dengan suatu dorongan: Mendaki. Pendakian disini dalam arti yang lebih luas, yaitu menggerakkan tujuan hidup ke depan, apapun tujuan itu. Pendaki tersebut diantaranya;

Quitters. Quitters adalah orang-orang yang berhenti. Mereka menghentikan pendakian. Mereka menolak kesempatan yang diberikan oleh gunung. Mereka mengabai-kan, menutupi atau meninggalkan dorongan inti yang manusiawi untuk mendaki, dan dengan demikian juga meninggalkan banyak hal yang ditawarkan oleh kehidupan (Stoltz, 2000: 19).

Quitters menganggap kehidupan adalah sesuatu yang tidak menyenangkan. Mereka mengabaikan potensi yang dimiliki, melarikan diri dari pendakian, dan meninggalkan impian yang dimilikinya untuk menenangkan hati dan pikiran (Stoltz, 2000).

Quitters di tempat kerja, bekerja sekedar cukup untuk hidup, terhenti dengan kepuasan akan tercapainya kebutuhan fisiologis saja. Mereka memiliki ambisi dan semangat yang minim, juga mengambil sedikit mungkin resiko yang ada, dan biasanya tidak kreatif (Stoltz, 2000).

Campers. Kelompok individu yang kedua adalah campers atau orang-orang yang berkemah. Stoltz (2000: 19) mengatakan bahwa karena bosan, mereka mengakhiri penda-kiannya dan mencari tempat datar yang rata dan nyaman sebagai tempat bersembunyi dari situasi yang tidak bersahabat.

Campers sekurang-kurangnya telah menanggapi tantangan pendakian itu. Mereka telah mencapai tingkat tertentu. Pendakian yang tidak selesai itu oleh sementara orang dianggap sebagai "kesuksesan" (Stoltz, 2000).

Para campers lelah mendaki, mereka merasa senang dengan apa yang sudah ada dan sudah mereka miliki. Mereka mengorbankan kemungkinan yang ada, melepaskan kesempatan untuk maju, tidak mau keluar dari zona nyaman, dan tidak mau mengembangkan diri. Pada hierarki kebutuhan Maslow, campers hanya sampai pada level 2 atau pada kebutuhan akan rasa aman.

Di tempat kerja, campers sudah memiliki sedikit inisiatif, semangat, dan beberapa usaha, tetapi mereka tidak menggunakan seluruh kemampuan yang dimilikinya. Campers mengerjakan pekerjaan yang cukup membuatnya tetap dipekerjakan, mereka selalu mengambil jalan yang aman (Stoltz, 2000). 
Climber. Climber atau pendaki, adalah orang yang membaktikan dirinya dan kehidu-pannya untuk terus melakukan pendakian. Tanpa menghiraukan latar belakang, keuntungan dan kerugian, nasib buruk atau nasib baik, para climber terus mendaki (Stoltz, 2000).

Climber bisa mencapai aktualisasi diri, mereka memahami tujuan yang ingin dicapai, mengetahui bahwa imbalan datang dalam bentuk manfaat-manfaat jangka panjang, bahkan mereka menyambut tantangan yang datang. Para climber yakin akan sesuatu yang lebih besar, mereka percaya bahwa segala sesuatu pasti bisa dilalui. Jika jalan buntu, climber akan mencari jalan lain. Climber terus-menerus melakukan introspeksi dan terus bertahan, mereka mungkin saja mundur sedikit agar terus bisa melanjutkan pendakian sampai puncak kesuksesan. Dalam dunia pekerjaan, climber menyambut tantangan baru, mereka bisa memotivasi diri mereka sendiri, dan bekerja dengan visi yang jelas, dan selalu menemukan cara agar segala sesuatu terjadi (Stoltz, 2000).

\section{Teori Dasar AQ}

Menurut Stoltz (2000) karya ini disusun berdasarkan hasil riset penting lusinan ilmuwan kelas atas dan lebih dari 500 kajian di seluruh dunia dengan memanfaatkan tiga cabang ilmu pengetahuan.

Ilmu pengetahuan yang membentuk AQ diantaranya yaitu;

Psikologi Kognitif. Melalui pendekatan Kognitif, tingkah laku merupakan hasil dari pemrosesan informasi yang terjadi di dalam diri manusia. Manusia tidak hanya menjadi reseptor pasif terhadap stimuli, tetapi pikiran manusia secara aktif memproses informasi yang diterima, mengubahnya menjadi tanda-tanda yang digunakan otak dan akan memproduksinya ketika dibutuhkan (Stoltz, 2000).

Orang yang merespon kesulitan sebagai sesuatu yang berlangsung lama, memiliki jangkauan jauh, bersifat internal, dan di luar kendali mereka, akan menderita, sementara orang yang merespon kesulitan sebagai sesuatu yang pasti akan cepat berlalu, terbatas, eksternal, dan berada dalam kendali mereka, akan berkembang dengan pesat. Respon seseorang terhadap kesulitan memengaruhi semua segi efektivitas, kinerja, dan kesuksesan. Kita merespon kesulitan dengan pola-pola yang konsisten dan di bawah sadar. Jika tidak dihambat, pola-pola ini bersifat tetap seumur hidup seseorang (Stoltz, 2000: 115).

Neurofisiologi. Neurofisiologi adalah studi tentang respons-respons sistem syaraf terhadap rangsangan dari luar (Ling dan Catling, 2012). Otak idealnya diperlengkapi untuk membentuk kebiasaan-kebiasaan. Kebia-saan seseorang dalam merespon kesulitan dapat dihentikan dan segera diubah. Jika diganti, kebiasaan-kebiasaan lama akan lenyap, sementara kebiasaankebiasaan baru akan berkembang (Stoltz, 2000: 115).

Psikoneuroimunologi. Istilah "psiko" mengacu pada proses psikologis seperti emosi dan persepsi; "neuro" terkait sistem syaraf dan endokrin; dan "imunologi" mengacu pada sistem kekebalan yang membuat tubuh mampu melawan penyakit dan infeksi (Wade dan Travis, 2007: 290).

Stoltz (2000) mengatakan bahwa ada hubungan langsung antara respon seseorang terhadap kesulitan dengan kesehatan mental dan jasmaniahnya. Pengendalian sangat penting bagi kesehatan dan umur panjang. Menurut Stoltz (2000) bagaimana seseorang merespon kesulitan (AQ) memengaruhi fungsi-fungsi kekebalan, kesembuhan dari operasi, dan kerawanan terhadap penyakit yang mengancam jiwa. Pola repon yang lemah terhadap kesulitan dapat menimbulkan depresi.

Ketiga dasar ilmu ini bersama-sama membentuk AQ. Pada akhirnya AQ akan menghasilkan sebuah pemahaman, ukuran, serta serangkaian alat baru untuk meningkatkan efektivitas manusia. 


\section{Dimensi AQ}

Control (Kendali). Kendali umumnya bersifat internal dan seringnya sangat bersifat individual, karena diri sendirilah yang bisa mengendalikan respon yang diterima dari lingkungan. Harapan dan tindakan akan tumbuh jika diwadahi oleh suatu kemampuan yang dinamakan kendali (Stoltz, 2000).

Control atau kendali adalah kemampuan seseorang dalam mengendalikan dan mengelola sebuah peristiwa yang menimbulkan kesulitan di masa mendatang. Kendali diri ini akan berdampak pada tindakan selanjutnya atau respon yang dilakukan individu yang bersangkutan, tentang harapan dan idealitas individu untuk tetap berusaha keras mewujudkan keinginannya walau sesulit apapun keadaannya sekarang (Sho'imah, 2010).

Origin - Ownership (Asal Usul dan Pengakuan). Origin - Ownership atau biasa disebut $\mathrm{O} 2$ adalah satu kesatuan yang tidak bisa dipisahkan. Origin yaitu asal usul dari kesulitan yang dialami; siapa atau apa yang menyebabkan kesulitan itu terjadi. Hal ini berkaitan dengan rasa bersalah. Rasa bersalah melihat sejauh mana seseorang mempermasalahkan dirinya, orang lain, atau lingkungannya saat menjadi sumber kesulitan atau kegagalan yang dialami.

Rasa bersalah yang tepat akan menggugah seseorang untuk bertindak sedangkan rasa bersalah yang terlalu besar akan menciptakan kelumpuhan. Poin ini merupakan pembukaan dari poin ownership. Ownership mengungkap sejauh mana seseorang mengakui akibat-akibat kesulitan dan kesediaan seseorang untuk bertanggung jawab atas kesalahan atau kegagalan tersebut (Sho'imah, 2010: 139).

Reach (Jangkauan). Sejauh mana kesulitan ini akan merambah kehidupan seseorang menunjukkan bagaimana suatu masalah mengganggu aktivitas lainnya, sekalipun tidak berhubungan dengan masalah yang sedang dihadapi. Adversity quotient yang rendah pada individu akan membuat kesulitan merembes ke segi-segi lain dari kehidupan seseorang (Sho'imah, 2010: 140).

Semakin rendah skor seseorang, semakin besar pula kemungkinan adanya anggapan bahwa peristiwa buruk yang terjadi adalah suatu bencana, dan setelah itu membiarkannya meluas pada situasi yang lain (Stoltz, 2000).

Endurance (Daya Tahan). Endurance mempertanyakan dua hal yang berkaitan, yaitu berapa lama kesulitan ini akan berlangsung dan berapa lama penyebab kesulitan ini akan berlangsung. Jika skor dimensi ini rendah, maka semakin besar kemungkinannya kesulitan atau penyebabpenyebab kesulitan yang dihadapi dianggap akan berlangsung lama (Stoltz, 2000).

Endurance melihat ketahanan individu, yaitu sejauh mana seseorang dapat memecahkan masalah. Dengan demikian aspek ini melihat berapa lama kesulitan dan penyebab kesulitan itu akan berlangsung. Hal ini berkaitan dengan pandangan individu terhadap kepermanenan dan ketemporeran kesulitan yang berlangsung. Efek dari aspek ini adalah pada harapan tentang baik atau buruknya keadaan masa depan. Makin tinggi daya tahan seseorang, makin mampu menghadapi berbagai kesukaran yang dihadapinya (Sho'imah, 2010: 140).

\section{Prestasi Akademik}

Menurut Yuniah (2006), pengertian prestasi akademik adalah hasil pelajaran yang diperoleh dari kegiatan belajar di sekolah atau perguruan tinggi yang bersifat kognitif dan biasanya ditentukan melalui pengukuran dan penilaian. Prestasi akademik dinilai berdasarkan IPK (Indeks Prestasi Kumulatif).

Prestasi akademik adalah nilai atau ukuran yang diperoleh sebagai hasil karya akademis yang didapatkan melalui tes yang dibakukan, untuk menggambarkan penguasaan seseorang terhadap hal-hal yang sudah dipelajarinya. 
Menurut Aprilia (2015), prestasi akademik mahasiswa dapat dilihat dari nilai indeks prestasi kumulatif (IPK) dan masa studi. IPK menjadi salah satu syarat dalam melamar pekerjaan, sehingga penting bagi mahasiswa untuk memiliki IPK yang baik.

Menurut Hartono (2011), Prestasi akademik mahasiswa dapat dipengaruhi oleh dua faktor yaitu faktor internal dan faktor eksternal. Adapun yang termasuk faktor internal adalah faktor yang bersumber dari diri mahasiswa, mencakup faktor: (1) kemampuan atau kecerdasan; (2) kesehatan fisik, psikis, dan sosial; (3) motivasi intrinsik; (4) minat; serta (5) perhatian.

Sedangkan faktor eksternal adalah faktor yang bersumber dari luar diri mahasiswa, yang mencakup faktor: (1) kurikulum dan model pembelajaran; (2) iklim dan suasana pembelajaran; (3) motivasi ekstrinsik; dan (4) infrastruktur pembelajaran yang terdiri dari ruang kuliah dan kelengkapannya, laboratorium, serta perpustakaan.

Menurut Syah (2010: 129-136) secara global, faktor-faktor yang memengaruhi belajar siswa dapat dibedakan menjadi tiga macam yakni;

Faktor Internal. Faktor dalam diri siswa yakni kondisi jasmani dan rohani siswa. Pada faktor jasmani/ aspek fisiologis, kondisi umum jasmani dan tonus (tegangan otot) yang menandai tingkat kebugaran organ-organ tubuh dan sendisendinya, dapat meme-ngaruhi semangat dan intensitas siswa dalam mengikuti pelajaran.

Kondisi organ-organ khusus siswa, seperti tingkat kesehatan indera pendengar dan indera penglihat, juga sangat memengaruhi kemampuan siswa dalam menyerap informasi dan pengetahuan, khususnya yang disajikan di kelas.

Pada faktor rohani/ faktor psikologis, yang pada umumnya dipandang lebih esensial dapat memengaruhi kuantitas dan kualitas perolehan belajar siswa adalah tingkat kecerdasan/ intelegensi siswa, sikap siswa, bakat siswa, minat siswa, dan motivasi siswa.

\section{a. Faktor Eksternal}

Faktor eksternal terdiri atas dua macam, yakni faktor lingkungan sosial dan faktor lingkungan nonsosial. Lingkungan sosial sekolah seperti para guru, para tenaga kependidikan, dan teman-teman sekelas dapat memengaruhi semangat belajar seorang siswa. Selanjutnya masyarakat dan tetangga juga teman-teman sepermainan di sekitar perkampungan siswa tersebut. Lingkungan sosial yang paling banyak memengaruhi belajar adalah orangtua dan keluarga siswa itu sendiri.

Faktor-faktor yang termasuk lingkungan nonsosial ialah gedung sekolah dan letaknya, rumah tempat tinggal keluarga siswa dan letaknya, alat-alat belajar, keadaan cuaca, dan waktu belajar yang digunakan siswa.

Faktor Pendekatan Belajar. Pendekatan belajar dapat dipahami sebagai keefektifan segala cara atau strategi yang digunakan siswa dalam menunjang efektivitas dan efisiensi proses belajar materi tertentu.

\section{Metode Penelitian}

Penelitian ini menggunakan pendekatan dengan metode penelitian kuantitatif. Penelitian kuantitatif merupakan metodemetode untuk menguji teori-teori tertentu dengan cara meneliti hubungan antar variabel. Variabel-variabel ini diukur sehingga data yang terdiri dari angka-angka dapat dianalisis berdasarkan prosedurprosedur statistik (Creswell, 2013: 5).

Jika ditinjau dari tujuan, penelitian ini menggunakan jenis penelitian eksplanatori. Menurut Silalahi (2012: 30), penelitian eksplanatori atau eksplanatif atau eksplanasi bertujuan untuk menjelaskan hubungan antara dua atau lebih gejala variabel. Penelitian ini semakin dikenal dengan sebutan penelitian korelasional. Dalam penelitian ini, peneliti menggunakan penelitian korelasional dengan tipe penelitian kausal. Penelitian korelasional 
(correlational) yaitu metode penelitian yang ditujukan untuk menjelaskan hubungan antara satu variabel dengan variabel lainnya (UIN, 2012).

Penelitian kausal meneliti hubungan sebab-akibat antara dua variabel atau lebih. Dalam penelitian kausal, ingin dijelaskan pengaruh perubahan variasi nilai dalam suatu variabel terhadap perubahan variasi nilai dalam satu atau lebih variabel lain (Silalahi, 2012: 33).

Dalam penelitian ini, variabel penelitian yang digunakan yaitu adversity quotient sebagai variabel prediktor, dan prestasi akademik sebagai variabel kriterion.

\section{Subjek Penelitian}

Populasi dalam penelitian ini adalah seluruh mahasiswa Fakultas Psikologi UIN SGD angkatan 2013. Berdasarkan data dari Bagian Akademik Fakultas Psikologi, secara keseluruhan mahasiswa angkatan 2013 yang aktif sampai semester 6 dan memiliki IP semester 5 berjumlah 147 orang.

Sampling adalah cara pengumpulan data apabila yang diselidiki adalah elemen sampel dari suatu populasi (Supranto, 2008: 23). Teknik sampling yang digunakan dalam penelitian ini adalah teknik sampel acak (probability random). Berdasarkan situasi dan keadaan yang memungkinkan pada saat pengambilan data, pengambilan sampel dilakukan dengan menggunakan teknik sampling dengan jenis simple random sampling.

Simple random sampling adalah sampling dimana pemilihan elemen populasi dilakukan sedemikian rupa sehingga setiap elemen tersebut mempunyai kesempatan yang sama untuk terpilih (Supranto, 2008: 24). Jumlah sampel minimum yang diambil ditentukan dengan rumus dari Slovin.

Sampel adalah seb;agian yang diambil dari populasi (Sudjana, 2005: 6). Setelah dilakukan perhitungan dari jumlah populasi sebanyak 147 orang, didapatkan sampel minimum untuk penelitian ini adalah sebanyak 107 orang mahasiswa Fakultas Psikologi UIN SGD Bandung angkatan 2013.

\section{Teknik Pengumpulan Data}

Pengumpulan data dilakukan melalui suatu proses untuk mendapatkan data empiris dari subjek penelitian. Dalam penelitian ini, metode pengumpulan data dilakukan dengan menggunakan angket.

Teknik angket yaitu mengajukan sejumlah pertanyaan secara tertulis dan terperinci kepada responden untuk mendapatkan jawaban sesuai dengan yang dikehendaki (UIN, 2014: 27).

Instrumen yang digunakan yaitu skala adversity quotient dari Stoltz, yang dinamakan adversity response profile (ARP) quick take yang dimodifikasi oleh peneliti untuk setting pendidikan.

Dalam mengisi kuesioner ini, responden diminta untuk menempatkan diri mereka sesuai dengan hambatan yang harus diilustrasikan terlebih dahulu, setelah itu barulah responden mengisi pernyataan yang paling mencerminkan keadaannya saat menghadapi hambatan tersebut.

Skor AQ ditunjukkan dengan skor yang diperoleh responden, yaitu semakin tinggi skor yang diperoleh menunjukkan semakin tinggi tingkat AQ yang dimilikinya. Begitu pula sebaliknya, semakin rendah skor yang diperoleh menunjukkan semakin rendah tingkat AQ yang dimilikinya.

Penyebaran soal untuk ARP dilakukan mengikuti ARP yang asli, yaitu 10 item untuk dimensi control (kendali), 5 item untuk dimensi origin (asal-usul), 5 item untuk dimensi owner (pengakuan), 10 item untuk dimensi reach (jangkauan), dan 10 item untuk dimensi endurance (daya tahan).

Dalam pengukuran prestasi akademik, dilakukan pengambilan data sekunder yang diperoleh dari Bagian Akademik Fakultas Psikologi UIN SGD Bandung. Prestasi 
akademik dalam penelitian ini dilihat dari Indeks Prestasi Kumulatif (IPK).

Dalam memperoleh data, peneliti menggunakan alat bantu ARP yang dimodifikasi untuk setting pendidikan. Untuk memastikan data tersebut dapat memenuhi kriteria yang ditetapkan, maka peneliti melakukan uji coba alat ukur sebelum menggunakannya.

ARP adalah kuesioner yang termasuk ke dalam skala diferensi semantik. Azwar (2009: 174) mengatakan bahwa salah satu cara yang dapat ditempuh guna memilih item atau pasangan kata sifat yang paling baik adalah dengan menghitung korelasi antara distribusi skor setiap item dengan skor total skala. Untuk menghitung korelasi tersebut dapat digunakan formula hitung korelasi product-moment pearson.

Kemudian, dari keseluruhan item yang telah dihitung koefisien korelasinya dan dipilih itu dapat kita ambil sebagian item atau pasangan kata sifat yang memiliki koefisien tertinggi saja. (Azwar, 2009: 174).

Skala diferensi semantik mengharuskan adanya seleksi pada item yang telah dibuat peneliti. 20 item terbaik dipilih berdasarkan kriteria yang memiliki koefisien korelasi tertinggi. Dari 40 item ARP, 20 item terbaik digunakan sebagai item terpakai.

Setelah dilakukan analisis item, dilakukan uji validitas untuk melihat apakah skala ARP benar-benar mampu mengukur tingkat AQ mahasiswa. Validitas skala sikap banyak disandarkan pada relevansi isi pertanyaan yang disusun berdasarkan rancangan yang tepat (Azwar, 2009: 176).

Uji validitas ini adalah uji validitas konstruk, dimana nilai koefisien validitas diperoleh dari perhitungan korelasi antara skor total dari setiap dimensi dengan skor total pada skala. Nilai koefisien korelasi bisa didapatkan melalui perhitungan formula korelasi product-moment pearson.

Setelah dilakukan uji validitas untuk 4 dimensi AQ, didapatkan hasil yaitu untuk dimensi control nilai validitasnya sebesar 0.585 (validitas sedang), dimensi originowner nilai validitasnya sebesar 0.350 (validitas rendah), dimensi reach nilai validitasnya sebesar 0.569 (validitas sedang), dan dimensi endurance nilai validitasnya sebesar 0.781 (validitas tinggi).

Langkah terakhir dalam pengujian instrumen adalah melakukan uji reliabilitas. Ada banyak cara dalam menghitung koefisien reliabilitas suatu skala. Pada penelitian ini, digunakan metode cronbach alpha reliability.

Berdasarkan uji reliabilitas yang telah dilakukan, diketahui koefisien reliabilitas untuk skala ARP yang telah dimodifikasi ini adalah sebesar 0.707 (reliabilitas tinggi).

Hipotesis adalah asumsi atau dugaan mengenai sesuatu hal yang dibuat untuk menjelaskan hal itu yang sering dituntut untuk melakukan pengecekannya (Sudjana, 2005: 219). Hipotesis ini terbagi menjadi dua, yaitu $\mathrm{H}_{0}$ (hipotesis nol) dan $\mathrm{H}_{1}$ (hipotesis pengganti).

Hipotesis penelitian yang telah dijelaskan sebelumnya diturunkan menjadi hipotesis statistik sebagai berikut:

$$
\begin{aligned}
\mathrm{H}_{0}: & \beta 1=0 \rightarrow \text { Tidak terdapat } \\
& \text { pengaruh signifikan adversity } \\
& \text { quotient terhadap prestasi } \\
& \text { akademik mahasiswa Psikologi } \\
& \text { angkatan } 2013 . \\
\mathrm{H}_{1}: & \beta 1 \neq 0 \rightarrow \text { Terdapat pengaruh } \\
& \text { signifikan adversity quotient } \\
& \text { terhadap prestasi akademik } \\
& \text { mahasiswa Psikologi angkatan } \\
& \text { 2013. }
\end{aligned}
$$

\section{Teknik Analisis Data}

Teknik analisis data pada penelitian ini menggunakan analisis regresi sederhana, karena ingin melihat pengaruh dari variabel prediktor terhadap variabel kriterion.

Analisis regresi adalah analisis yang menyatakan hubungan antara variabelvariabel (Sudjana, 2005). Langkah-langkah perhitungan dimulai dengan pengujian 
asumsi klasik (Uji normalitas, uji linearitas, uji heteroskedastisitas).

Uji normalitas dilakukan untuk melihat apakah sebaran data dari sampel penelitian adalah normal. Uji normalitas pada penelitian ini menggunakan uji Kolmogorov-Smirnov, karena uji ini baik digunakan untuk ukuran sampel kurang dari 200

Uji linearitas dipergunakan untuk melihat apakah model yang dibangun mempunyai hubungan linear atau tidak. Uji heteroskedastisitas merupakan pengujian untuk melihat apakah terdapat kesamaan variabel dari pengamatan yang satu ke pengamatan yang lain.

Setelah melakukan uji asumsi klasik dan data dinyatakan memenuhi syarat untuk dilakukan persamaan regresi, maka langkah selanjutnya adalah melakukan analisis regresi linear sederhana.

Formula yang digunakan untuk menghitung regresi sederhana adalah sebagai berikut:

$\hat{\mathrm{Y}} \quad=\beta 0+\beta 1 \mathrm{X}$

$\hat{\mathrm{Y}} \quad=$ Skor prediksi variabel dependen

$\beta 0=$ Harga konstan

$\beta 1=$ Koefisien Regresi

$\mathrm{X}=$ Skor variabel independen

Dalam mengkategorikan subjek, peneliti akan memperhatikan norma kelas dengan menggunakan rentang dari nilai minimum dan maksimum. Kemudian setelah diketahui rentangnya, subjek akan dikategorikan menjadi 3 kategori, yaitu tinggi, sedang, atau rendah untuk kategorisasi IPK, dan tinggi (climber), sedang (camper), atau rendah (quitter) untuk kategorisasi AQ.

\section{Hasil Penelitian Dan Pembahasan}

Hasil penelitian akan dibahas mengenai seberapa besar pengaruh adversity quotient terhadap prestasi akademik pada mahasiswa Fakultas Psikologi angkatan 2013. Pengujian hipotesis dilakukan dengan teknik analisis regresi linear sederhana. Sebelum dilakukan analisis regresi, dilakukan uji asumsi klasik terlebih dahulu. Kemudian dalam hasil penelitian ini juga dibahas mengenai koefisien determinasi dan bagaimana analisis deskriptifnya.

Uji asumsi klasik dilakukan dengan cara uji normalitas, uji linearitas, dan uji heteroskedastisitas.

Uji normalitas pada penelitian ini menggunakan Kolmogorov-Smirnov. Setelah dilakukan perhitungan, didapatkan hasil untuk nilai signifikansi dari prestasi akademik (IPK) adalah 0.070 dan nilai signifikansi AQ adalah 0.069. Kedua distribusi tersebut memiliki nilai $>\alpha(0.05)$, sehingga dapat disimpulkan bahwa kedua data berdistribusi normal.

Selain dilihat dari nilai signifikansi, kesimpulan dari uji normalitas bisa dilihat dari grafik. Berikut ini grafik untuk distribusi skor prestasi akademik (IPK) dan distribusi skor AQ.

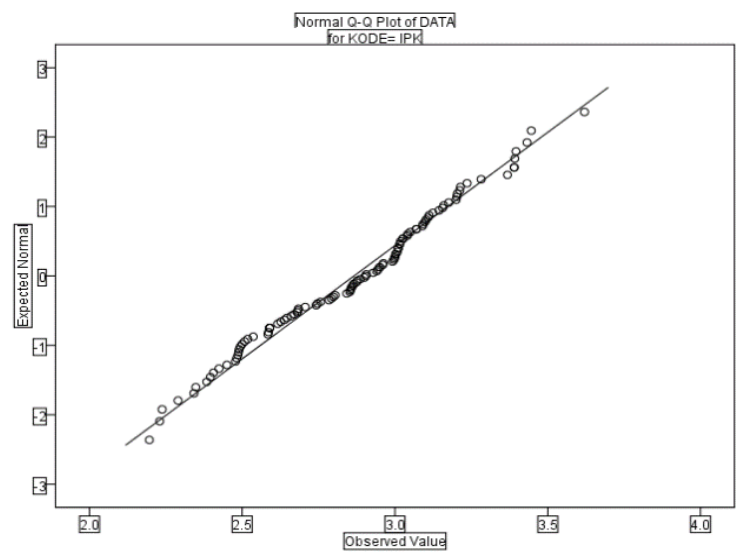

Gambar 1. Hasil uji normalitas IPK.

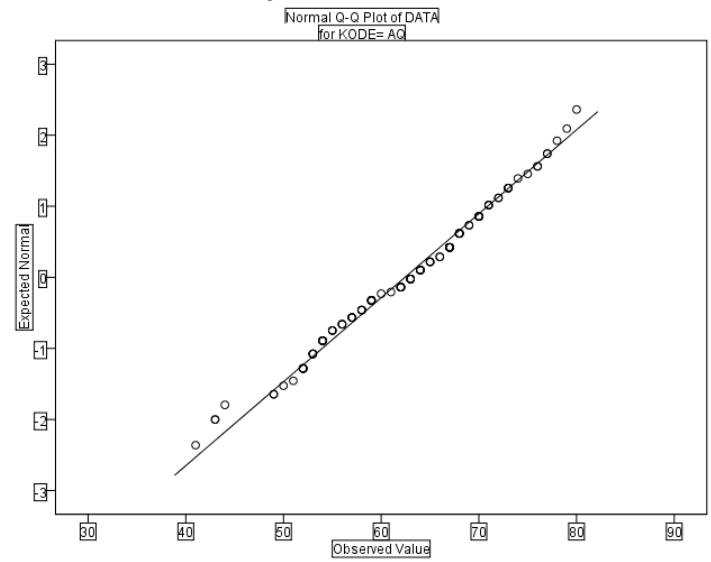

Gambar 2. Hasil uji normalitas AQ. 
Menurut Santoso (2012: 233) jika data menyebar di sekitar garis diagonal dan mengikuti arah garis diagonal, maka model regresi memenuhi asumsi normalitas. Terlihat dari gambar 1 dan gambar 2 bahwa skor prestasi akademik (IPK) dan skor AQ menyebar di sekitar garis dan mengikuti arah garis diagonal, maka kedua data tersebut berdistribusi normal.

Setelah dilakukan perhitungan untuk uji linearitas, hasil nilai signifikansi (0.036) $<\alpha$ (0.05). Oleh karena itu $\mathrm{H}_{0}$ ditolak, sehingga didapatkan kesimpulan bahwa kedua data linear.

Perhitungan untuk uji heteroskedastisitas diketahui bahwa nilai signifikansi adalah 0.661. Hasil untuk nilai signifikansi dari AQ $(0.661)>\alpha(0.05)$, sehingga $\mathrm{H}_{0}$ ditolak. Oleh karena itu dapat disimpulkan bahwa tidak terjadi masalah heteroskedastisitas untuk AQ.

Pada uji asumsi klasik dapat disimpulkan bahwa data memenuhi syarat untuk dilakukan uji regresi linear sederhana.

Setelah ditetapkan persamaan regresi, selanjutnya adalah melakukan analisis regresi untuk melihat apakah terdapat pengaruh AQ terhadap prestasi akademik.

Hasil untuk nilai signifikansi (0.029) < $\alpha(0.05)$, sehingga $\mathrm{H}_{0}$ ditolak. Oleh karena itu dapat disimpulkan bahwa terdapat pengaruh AQ terhadap prestasi akademik (IPK).

Persamaan regresi untuk penelitian ini jika dilihat dari tabel coefficients pada kolom B adalah:

$\hat{\mathbf{Y}}=\boldsymbol{\beta} \mathbf{0}+\boldsymbol{\beta} 1 \mathbf{X}$

$\hat{\mathrm{Y}}=2.393+0.008 \mathrm{X}$

Nilai kedua $\beta$ adalah positif, sehingga disimpulkan ada hubungan positif antara AQ dengan prestasi akademik (IPK). Koefisien regresi AQ adalah 0.008, maka jika skor AQ naik 1 angka, maka skor prestasi akademik (IPK) naik sebesar 0.008 .

Setelah diketahui bahwa terdapat pengaruh AQ terhadap prestasi akademik (IPK), besaran pengaruh dapat dilihat melalui koefisien determinasi yang akan dicari dengan formula sebagai berikut:

$\mathrm{KD}=\mathrm{r}^{2} \times 100 \%$

Diketahui bahwa nilai $\mathrm{r}^{2}$ adalah sebesar 0.044. Maka koefisien determinasi dari pengaruh AQ terhadap prestasi akademik (IPK) adalah sebesar $4.4 \%$. Oleh karena itu prestasi akademik (IPK) dipengaruhi sebesar $4.4 \%$ oleh AQ.

Nilai Standard Error of the Estimate (SEE) sebesar 0.301072 (untuk variabel prestasi akademik yang dilihat dari nilai IPK). Jika dibandingkan dengan Standard Deviasi (SD) yang bernilai 0.306455, maka nilai SEE lebih kecil.

Pada saat nilai SEE (0.301072) lebih kecil dari nilai SD (0.306455), artinya adalah angka tersebut baik untuk prediktor dalam menentukan prestasi akademik dalam setting pendidikan.

Analisis deskriptif dilakukan untuk mendeskripsikan hasil penelitian. Diketahui bahwa rata-rata IPK mahasiswa adalah 2.87 dan rata-rata AQ mahasiswa adalah 62.42. Nilai tengah untuk IPK adalah 2.90 dan untuk AQ adalah 63.

Jarak dari IPK tertinggi sampai IPK terrendah adalah sebesar 1.424, sedangkan jarak dari skor AQ tertinggi sampai skor AQ terrendah adalah sebesar 39.

Nilai terkecil untuk IPK adalah 2.196 dan nilai terbesar untuk IPK adalah 3.62. Nilai terkecil AQ adalah 41 dan nilai terbesar AQ adalah 80. Berdasarkan datadata tersebut, maka dibuat kategorisasi untuk AQ dan kategorisasi untuk prestasi akademik (IPK), serta dibuat juga tabulasi silang dari kedua variabel tersebut.

Distribusi skor AQ dari responden sebanyak 109 mahasiswa dapat dilihat dari grafik pada gambar 3 . 


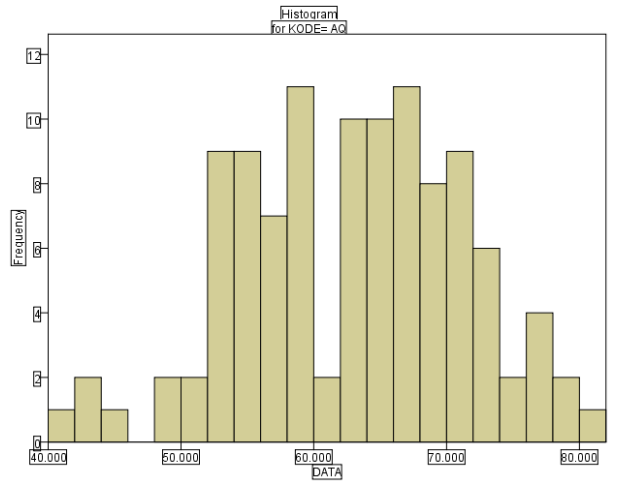

Gambar 3. Distribusi skor AQ.

Tabel 1

Distribusi Frekuensi Tingkat $A Q$

\begin{tabular}{lcc}
\hline \multicolumn{1}{c}{ Kategori } & Frekuensi & Prosentase (\%) \\
\hline $\begin{array}{l}\text { Tinggi } \\
\text { (Climbers) }\end{array}$ & 41 & $37.61 \%$ \\
$\begin{array}{l}\text { Sedang } \\
\text { (Campers) }\end{array}$ & 51 & $46.79 \%$ \\
$\begin{array}{l}\text { Rendah } \\
\text { (Quitters) }\end{array}$ & 17 & $15.60 \%$ \\
Jumlah & 109 & $100 \%$ \\
\hline
\end{tabular}

Diketahui bahwa mahasiswa Fakultas Psikologi UIN SGD Bandung angkatan 2013 kebanyakan berada pada tingkat adversity quotient yang sedang (Campers).

Distribusi skor IPK dari responden sebanyak 109 mahasiswa dapat dilihat dari grafik pada gambar 4 .

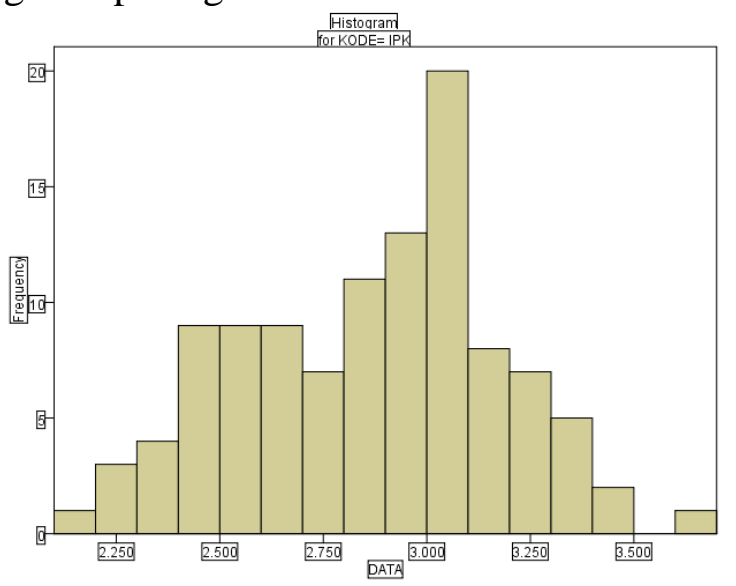

Gambar 4. Distribusi IPK.

Kategorisasi untuk IPK dapat dilihat pada tabel 2 .
Tabel 2

Distribusi Frekuensi IPK

\begin{tabular}{lcc}
\hline \multicolumn{1}{c}{ Kategori } & Frekuensi & Prosentase (\%) \\
\hline Tinggi & 18 & $16.51 \%$ \\
Sedang & 60 & $55.05 \%$ \\
Rendah & 31 & $28.44 \%$ \\
Jumlah & 109 & $100 \%$ \\
\hline
\end{tabular}

Diketahui bahwa mahasiswa Fakultas Psikologi UIN SGD Bandung angkatan 2013 kebanyakan berada pada tingkat IPK yang sedang.

Dalam mengetahui secara rinci hubungan AQ dengan prestasi akademik (IPK) pada mahasiswa Fakultas Psikologi UIN SGD Bandung angkatan 2013, peneliti membuat tabulasi silang.

Diketahui bahwa kebanyakan mahasiswa Fakultas Psikologi UIN SGD Bandung angkatan 2013 memiliki IPK sedang dan skor AQ juga sedang (campers).

Tabel 3

Distribusi Frekuensi Tabulasi Silang

\begin{tabular}{|c|c|c|c|c|}
\hline & \multicolumn{4}{|c|}{$\mathbf{A Q}$} \\
\hline & $\begin{array}{l}\text { Tinggi } \\
\text { (Climbers) }\end{array}$ & $\begin{array}{l}\text { Sedang } \\
\text { (Campers) }\end{array}$ & $\begin{array}{l}\text { Rendah } \\
\text { (Quitters) }\end{array}$ & $\sum$ \\
\hline Tinggi & 9 & 8 & 1 & 18 \\
\hline IDK Sedang & 21 & 31 & 8 & 60 \\
\hline${ }^{1 P K}$ Rendah & 11 & 12 & 8 & 31 \\
\hline$\sum$ & 41 & 51 & 17 & 109 \\
\hline
\end{tabular}

\section{Pembahasan}

Pada bagian ini pembahasan akan mengacu pada hasil perhitungan dari analisis inferensial dan analisis deskriptif. Pertama-tama akan dibahas mengenai hasil analisis inferensial yang menggunakan analisis regresi sederhana.

Seperti yang telah dikemukakan sebelumnya bahwa penelitian ini bertujuan untuk melihat pengaruh adversity quotient terhadap prestasi akademik. AQ mengungkap seberapa jauh seseorang mampu bertahan menghadapi kesulitan yang dialaminya. AQ memprediksi siapa yang mampu dan siapa yang tidak mampu dalam mengatasi kesulitan. AQ juga memprediksi 
siapa yang akan menyerah ataupun bertahan (Stoltz, 2000).

AQ yang dimiliki mahasiswa menunjukkan kemampuannya dalam mengubah hambatan yang dialaminya pada masa perkuliahan baik itu dalam mengerjakan tugas individual, tugas kelompok, tugas praktikum, ujian, ataupun gabungan dari semuanya, menjadi peluang keberhasilan mencapai IPK yang sesuai dengan yang diharapkannya.

AQ mengungkap seberapa jauh mahasiswa mampu bertahan menghadapi kesulitan dalam perkuliahan. AQ juga mengungkap bagaimana kemampuan mahasiswa untuk mengatasi kesulitan tersebut. AQ memprediksi mahasiswa mana yang mampu dan mahasiswa mana yang tidak mampu dalam mengatasi kesulitan. AQ juga memprediksi mahasiswa yang akan gagal dan yang akan melampaui harapan-harapan atas usaha selama perkuliahan dan potensi yang dimilikinya. AQ juga mempredikisi mahasiswa yang akan menyerah ataupun yang bertahan untuk mengikuti perkuliahan di Fakultas Psikologi UIN SGD Bandung.

AQ dapat membantu mahasiswa dalam memperkuat kemampuan dan ketekunan mereka dalam menghadapi tantangan/ kesulitan dalam perkuliahan dengan tetap berpegang pada prinsip dan harapan mereka tanpa mempedulikan yang terjadi.

Berdasarkan hasil pengolahan data melalui analisis statistik, diperoleh hasil bahwa $\mathrm{H}_{0}$ ditolak dan $\mathrm{H}_{1}$ diterima. Hal ini menunjukkan bahwa adversity quotient berpengaruh secara signifikan terhadap prestasi akademik pada mahasiswa Fakultas Psikologi UIN SGD.

Para mahasiswa memiliki kemampuan untuk bertahan saat menemui kesulitan yang ditemukan selama perkuliahan. Terlihat bahwa para mahasiswa dengan skor AQ tinggi dapat melampaui harapanharapan atas kinerja dan potensinya, hal ini terbukti melalui perolehan IPK mereka. Artinya, para mahasiswa angkatan 2013 dapat menghadapi kesulitan dalam perkuliahan, sehingga mereka bisa mendapatkan prestasi akademik (IPK) yang sesuai tujuannya.

Bentuk hubungan dari AQ dan prestasi akademik (IPK) dapat dilihat dari persamaan regresi $\hat{\mathbf{Y}}=\mathbf{2 . 3 9 3}+\mathbf{0 . 0 0 8} \mathbf{X}$. Prestasi akademik (IPK) adalah nilai prestasi akademik ditambah peningkatan nilai konstanta dikalikan dengan setiap penambahan nilai $A Q$. Bentuk hubungan ini cukup signifikan untuk menunjukkan adanya hubungan kausalitas antara AQ dengan prestasi akademik (IPK). Dari persamaan regresi tersebut diketahui bahwa setiap peningkatan 1 skor $\mathrm{AQ}$, maka prestasi akademik (IPK) akan meningkat sebesar 0.008 .

Hal ini juga disebabkan karena nilai kedua $\beta$ adalah positif, sehingga disimpulkan ada hubungan positif antara AQ dengan prestasi akademik (IPK). Maka semakin tinggi kemampuan AQ semakin tinggi pula prestasi akademik (IPK) yang dapat diraih oleh mahasiswa Fakultas Psikologi UIN SGD Bandung angkatan 2013.

AQ memengaruhi bahkan bisa menentukan daya saing, produktivitas seseorang, kreativitas, motivasi, bagaimana seseorang mengambil resiko, dan bagaimana melakukan perbaikan pada masa yang akan datang (Stoltz, 2000). Semua mahasiswa pada dasarnya memiliki skor AQ, sehingga daya saing dalam kelas selama perkuliahan, produktivitasnya yang tertuang dalam IPK, kreativitasnya dalam menyelesaikan masalah yang ada, motivasinya dalam belajar, bagaimana mereka mengambil resiko, dan bagaimana melakukan perbaikan pada masa yang akan datang bisa diprediksi dilihat dari skor AQ.

Berdasarkan perhitungan koefisien determinasi diketahui bahwa AQ berpengaruh terhadap prestasi akademik (IPK) sebesar $4.4 \%$.

Konsep IQ (intelligence quotient) telah lama dianggap sebagai penentu kesuksesan, namun ternyata beberapa orang dengan IQ tinggi tidak sedikit yang mengalami kega- 
galan. Setelah konsep IQ terkenal, Daniel Goleman memperkenalkan konsep baru mengenai kecerdasan, yaitu EQ (emotional quotient). Menurut Stoltz (2000) IQ dan EQ tidak cukup untuk memprediksi kesuksesan seseorang. Suksesnya pekerjaan dan hidup seseorang terutama ditentukan oleh adversity quotient (AQ). Menurut hasil penelitian diketahui bahwa pada mahasiswa, pengaruh AQ sebesar $4.4 \%$ dalam memprediksi kesuksesan mereka, yang tertuang dalam Indeks Prestasi Kumulatif yang mereka peroleh. Prosentase sisanya diperkirakan berasal dari faktor IQ, EQ, dan faktor lainnya.

Selain itu, menurut Hartono (2011), Prestasi akademik mahasiswa dapat dipengaruhi oleh dua faktor yaitu faktor internal dan faktor eksternal. Adapun yang termasuk faktor internal adalah faktor yang bersumber dari diri mahasiswa, mencakup faktor: (1) kemampuan atau kecerdasan; (2) kesehatan fisik, psikis, dan sosial; (3) motivasi intrinsik; (4) minat; serta (5) perhatian. Sedangkan faktor eksternal adalah faktor yang bersumber dari luar diri mahasiswa, yang mencakup faktor: (1) kurikulum dan model pembelajaran; (2) iklim dan suasana pembelajaran; (3) motivasi ekstrinsik; dan (4) infrastruktur pembelajaran yang terdiri dari ruang kuliah dan kelengkapannya, laboratorium, serta perpustakaan.

Menurut Syah (2010: 129-136) secara global, faktor-faktor yang memengaruhi belajar siswa dapat dibedakan menjadi tiga macam yakni; pertama, faktor internal. Faktor dalam diri siswa yakni kondisi jasmani dan rohani siswa. Pada faktor jasmani/ aspek fisiologis, kondisi umum jasmani dan tonus (tegangan otot) yang menandai tingkat kebugaran organ-organ tubuh dan sendi-sendinya, dapat memengaruhi semangat dan intensitas siswa dalam mengikuti pelajaran. Kondisi organ-organ khusus siswa, seperti tingkat kesehatan indera pendengar dan indera penglihat, juga sangat memengaruhi kemampuan siswa dalam menyerap informasi dan pengetahuan, khususnya yang disajikan di kelas. Pada faktor rohani/ faktor psikologis, yang pada umumnya dipandang lebih esensial dapat memengaruhi kuantitas dan kualitas perolehan belajar siswa adalah tingkat kecerdasan/ intelegensi siswa, sikap siswa, bakat siswa, minat siswa, dan motivasi siswa.

Kedua, faktor eksternal, yang terdiri atas dua macam, yakni faktor lingkungan sosial dan faktor lingkungan nonsosial. Lingkungan sosial sekolah seperti para guru, para tenaga kependidikan, dan temanteman sekelas dapat memengaruhi semangat belajar seorang siswa. Selanjutnya masyarakat dan tetangga juga teman-teman sepermainan di sekitar perkampungan siswa tersebut. Lingkungan sosial yang paling banyak memengaruhi belajar adalah orangtua dan keluarga siswa itu sendiri. Faktor-faktor yang termasuk lingkungan nonsosial ialah gedung sekolah dan letaknya, rumah tempat tinggal keluarga siswa dan letaknya, alat-alat belajar, keadaan cuaca, dan waktu belajar yang digunakan siswa.

Ketiga, faktor pendekatan belajar. Pendekatan belajar dapat dipahami sebagai keefektifan segala cara atau strategi yang digunakan siswa dalam menunjang efektivitas dan efisiensi proses belajar materi tertentu.

Oleh karena itu, perolehan dari hasil penelitian menunjukkan pengaruh yang rendah, disebabkan kecerdasan maupun kemampuan menghadapi perkuliahan hanyalah salah satu faktor internal yang menentukan prestasi akademik. Selain faktor internal, masih ada faktor eksternal, dan faktor pendekatan belajar yang juga memengaruhi prestasi akademik yang diperoleh mahasiswa tersebut.

Dimensi-dimensi AQ juga dibahas setelah terbukti bahwa adanya pengaruh AQ terhadap prestasi akademik mahasiswa.

Pertama, control (kendali). Harapan akan prestasi yang tinggi dan tindakan untuk mencapainya akan terlaksana jika diwadahi oleh kendali. Mahasiswa 
memiliki kemampuan dalam mengendalikan dan mengelola kesulitan yang mereka alami. Kendali diri ini akan berdampak pada tindakan selanjutnya atau respon yang dilakukan mahasiswa tersebut, untuk tetap berusaha keras mencapai IPK yang diinginkannya walau sesulit apapun keadaannya.

Kedua, origin-ownership (asal usul dan pengakuan). Origin yaitu asal usul dari kesulitan yang dialami; siapa atau apa yang menyebabkan kesulitan itu bisa terjadi, berkaitan dengan rasa bersalah. Rasa bersalah melihat sejauh mana seorang mahasiswa mempermasalahkan dirinya, orang lain (dosen, temannya, dan lain-lain), atau lingkungannya saat menjadi sumber kesulitan atau kegagalan yang dialami.

Rasa bersalah yang tepat akan menggugah seseorang untuk bertindak, sedangkan rasa bersalah yang terlampau besar akan menciptakan kelumpuhan. Poin ini merupakan pembukaan dari poin ownership. Ownership mengungkap sejauh mana seorang mahasiswa mengakui akibatakibat kesulitan dalam perkuliahan dan kesediaannya untuk bertanggung jawab atas kesalahan atau kegagalan tersebut.

Ketiga, reach (jangkauan). Sejauh mana kesulitan ini akan merambah hal lain pada kehidupan perkuliahan seorang mahasiswa menunjukkan bagaimana suatu masalah mengganggu aktivitas lainnya, sekalipun tidak berhubungan dengan masalah yang sedang dihadapi. Adversity quotient yang rendah pada mahasiswa akan membuat kesulitan meluas pada hal-hal lain dalam kehidupannya. Semakin rendah skor reach pada seorang mahasiswa, semakin besar pula kemungkinan dia menganggap bahwa peristiwa buruk yang terjadi adalah suatu bencana, dan setelah itu membiarkannya meluas pada situasi yang lain.

Keempat, endurance (daya tahan). Endurance mempertanyakan berapa lama kesulitan ini akan berlangsung dan berapa lama penyebab kesulitan ini akan berlangsung. Jika skor dimensi ini rendah, maka semakin besar kemungkinannya kesulitan atau penyebab-penyebab kesulitan yang dialami mahasiswa dianggap akan berlangsung lama. Endurance melihat ketahanan individu, yaitu sejauh mana seseorang dapat memecahkan masalah. Dengan demikian aspek ini melihat berapa lama kesulitan dan penyebab kesulitan itu akan berlangsung. Hal ini berkaitan dengan pandangan individu terhadap kepermanenan dan ketemporeran kesulitan yang berlangsung. Efek dari aspek ini adalah pada harapan tentang baik atau buruknya keadaan masa depan. Makin tinggi daya tahan seseorang, makin mampu menghadapi berbagai kesukaran yang dihadapinya (Sho'imah, 2010: 140).

Pembahasan selanjutnya mengenai hasil dari analisis deskriptif yang berfokus pada kategorisasi yang telah dilakukan sebelumnya. Dari total 109 mahasiswa Fakultas Psikologi UIN SGD Bandung angkatan 2013 yang menjadi subjek penelitian, diketahui sebanyak 41 mahasiswa memiliki AQ tinggi, atau disebut juga mereka adalah para climber.

Climber atau pendaki, adalah orang yang membaktikan dirinya dan kehidupannya untuk terus melakukan pendakian. Tanpa menghiraukan latar belakang, keuntungan dan kerugian, nasib buruk atau nasib baik, para climber terus mendaki (Stoltz, 2000).

Climber bisa mencapai aktualisasi diri, mereka memahami tujuan yang ingin dicapai, mengetahui bahwa imbalan datang dalam bentuk manfaat-manfaat jangka panjang, bahkan mereka menyambut tantangan yang datang. Jika jalan buntu, climber akan mencari jalan lain. Climber terus-menerus melakukan introspeksi dan terus bertahan, mereka mungkin saja mundur sedikit agar terus bisa melanjutkan pendakian sampai puncak kesuksesan. Dalam dunia pekerjaan, climber menyambut tantangan baru, mereka bisa memotivasi diri mereka sendiri, bekerja dengan visi yang jelas, dan selalu menemukan cara agar segala sesuatu terjadi (Stoltz, 2000). 
Para mahasiswa ini memiliki kemampuan untuk menghadapi kesulitan yang berat dan terus bergerak maju ke atas. Maksudnya adalah saat ada kesulitankesulitan dalam perkuliahan, mereka akan berusaha agar terbebas dari kesulitankesulitan itu. Mereka juga sudah menggunakan sebagian besar potensi yang berkembang setiap harinya.

Sebanyak 51 mahasiswa memiliki AQ yang sedang, atau mereka disebut juga para campers. Kelompok individu yang kedua ini disebut orang-orang yang berkemah.

Stoltz (2000: 19) mengatakan bahwa karena bosan, mereka mengakhiri pendakiannya dan mencari tempat datar yang rata dan nyaman sebagai tempat bersembunyi dari situasi yang tidak bersahabat.

Campers sekurang-kurangnya telah menanggapi tantangan pendakian. Mereka telah mencapai tingkat tertentu. Pendakian yang tidak selesai itu oleh sementara orang dianggap sebagai "kesuksesan" (Stoltz, 2000).

Para campers lelah mendaki, mereka merasa senang dengan apa yang sudah ada dan sudah mereka miliki. Mereka mengorbankan kemungkinan yang ada, melepaskan kesempatan untuk maju, tidak mau keluar dari zona nyaman, dan tidak mau mengembangkan diri. Pada hierarki kebutuhan Maslow, campers hanya sampai pada level 2 atau pada kebutuhan akan rasa aman.

Di tempat kerja, campers sudah memiliki sedikit inisiatif, semangat, dan beberapa usaha, tetapi mereka tidak menggunakan seluruh kemampuan yang dimilikinya. Campers mengerjakan pekerjaan yang cukup membuatnya tetap dipekerjakan, mereka selalu mengambil jalan yang aman (Stoltz, 2000).

Para mahasiswa yang ada pada kelompok ini cukup baik dalam menempuh lika-liku hidup sepanjang segala sesuatunya berjalan lancar. Namun para mahasiswa ini banyak mengalami kemunduran pada saat menghadapi kesulitan. Misalnya pada saat tugas perkuliahan dirasa berat, mereka akan meninggalkan tugas tersebut karena merasa frustrasi, tetapi pada akhirnya tugas tetap selesai walaupun kurang sempurna.

Kelompok terakhir yaitu terdapat 17 mahasiswa yang memiliki AQ rendah, atau disebut juga sebagai quitters. Para mahasiswa ini kurang memanfaatkan potensi yang dimilikinya.

Quitters adalah orang-orang yang berhenti. Mereka menghentikan pendakian. Mereka menolak kesempatan yang diberikan oleh gunung. Mereka mengabaikan, menutupi atau meninggalkan dorongan inti yang manusiawi untuk mendaki, dan dengan demikian juga meninggalkan banyak hal yang ditawarkan oleh kehidupan. (Stoltz, 2000: 19).

Quitters menganggap kehidupan adalah sesuatu yang tidak menyenangkan. Mereka mengabaikan potensi yang dimiliki, melarikan diri dari pendakian, dan meninggalkan impian yang dimilikinya untuk menenangkan hati dan pikiran (Stoltz, 2000).

Quitters di tempat kerja, bekerja sekedar cukup untuk hidup, terhenti dengan kepuasan akan tercapainya kebutuhan fisiologis saja. Mereka memiliki ambisi dan semangat yang minim, juga mengambil sedikit mungkin resiko yang ada, dan biasanya tidak kreatif (Stoltz, 2000).

Selanjutnya adalah pembahasan mengenai kategorisasi untuk prestasi akademik yang dapat dilihat dari IPK. Dari total 109 mahasiswa Fakultas Psikologi UIN SGD Bandung angkatan 2013 yang menjadi subjek penelitian, terdapat 18 mahasiswa yang memiliki IPK tinggi.

Para mahasiswa ini sudah memanfaatkan dengan baik faktor internal seperti kemampuan dan kecerdasan, motivasi, kesehatan dan lain-lain. Selain itu juga mahasiswa yang memiliki IPK tinggi sudah memanfaatkan dengan baik faktor eksternal seperti model pembelajaran, suasana, sarana dan prasarana yang memengaruhi prestasi akademik.

Sebanyak 60 mahasiswa memiliki IPK yang sedang. Lebih dari 50\% mahasiswa 
sudah cukup dalam memanfaatkan faktor internal dan eksternal dalam meraih prestasi akademik (IPK). Sedangkan 31 mahasiswa sisanya memiliki IPK yang rendah.

Dari hasil tabulasi silang diketahui sebanyak 9 mahasiswa memiliki IPK yang tinggi dan AQ yang tinggi (climbers), 31 mahasiswa memiliki IPK yang sedang dan AQ yang sedang (campers), dan 8 mahasiswa yang memiliki IPK rendah dan AQ yang rendah (quitters). Hal ini menunjukkan bahwa terdapat 48 atau $44.03 \%$ mahasiswa memiliki prestasi akademik (IPK) yang sesuai dengan usahanya dalam perkuliahan (AQ).

Walaupun begitu, 61 mahasiswa memiliki prestasi akademik (IPK) yang tidak sesuai dengan usaha yang dilakukannya (AQ). Sebanyak 55.97\% mahasiswa ini menunjukkan hasil yang sejalan dengan penelitian ini yang menunjukkan bahwa pengaruh AQ terhadap IPK sebesar $4.4 \%$ dan $95.6 \%$ sisanya berasal dari pengaruh variabel lain.

\section{Simpulan dan Saran}

Berdasarkan hasil analisis dan pembahasan, diperoleh kesimpulan bahwa terdapat pengaruh signifikan adversity quotient terhadap prestasi akademik pada mahasiswa Fakultas Psikologi UIN Sunan Gunung Djati Bandung angkatan 2013. Pengaruh AQ terhadap prestasi akademik adalah sebesar $4.4 \%$.

Hubungan dari AQ terhadap prestasi akademik adalah positif. Hal ini menunjukkan bahwa jika skor AQ mahasiswa meningkat, maka meningkat pula prestasi akademik (IPK) dari mahasiswa tersebut.

Hasil tabulasi silang menunjukkan bahwa sebanyak $28.44 \%$ mahasiswa Fakultas Psikologi UIN SGD Bandung angkatan 2013 memiliki niai IPK yang sedang dan juga tingkat AQ yang sedang (campers).

Berdasarkan hasil penelitian yang telah dilakukan, dengan keterbatasan dalam penelitian ini, peneliti mengajukan saransaran agar dapat menjadi pertimbangan.

Peneliti menyarankan untuk mahasiswa dengan skor AQ rendah untuk lebih mengasah potensi yang dimilikinya. Dengan demikian hambatan-hambatan dalam perkuliahan akan lebih mudah utuk dilewati dan pada akhirnya IPK akan meningkat.

Penelitian selanjutnya diharapkan mengembangkan skala AQ dengan cara memperbanyak item untuk dapat menggali dimensi-dimensi AQ lebih dalam, dan mengembangkan skala AQ untuk mendapatkan nilai validitas dan reliabilitas yang lebih tinggi lagi, dengan tujuan untuk meyakinkan bahwa item yang dibuat betulbetul valid dan reliabel dalam mengukur AQ seseorang.

Bidang penelitian untuk variabel AQ juga bisa diperluas, misalnya diterapkan pada setting Psikologi Eksperimen, Psikologi Klinis, Psikologi Perkembangan, dan bidang Psikologi lainnya. Penelitian selanjutnya bisa lebih spesifik dalam meneliti AQ, misalnya meneliti dimensidimensi AQ secara terpisah.

Banyak faktor yang memengaruhi ataupun dipengaruhi oleh AQ. Oleh karena itu variabel AQ bisa diteliti dengan variabel lainnya.

Variabel prestasi akademik bisa menggunakan pengukuran selain memperhatikan nilai IPK, misalnya menggunakan nilai salah satu mata kuliah, atau bisa juga dengan melihat pada nilai praktikum.

\section{Daftar Pustaka}

Aprilia, L. R. (2015). Evaluasi Prestasi Akademik Lulusan melalui Tracer Study Program Sarjana Alih Jenis Manajemen IPB, Diakses pada 25 Maret 2016 dari http://repository.ipb.ac.id/handle/1234 56789/75046? show=full

Azwar, S. (2009). Sikap Manusia: Teori dan Pengukurannya (Edisi ke 2), Yogyakarta: Pustaka Pelajar. 
Chakim, L. (2012). Mahasiswa serta Peran dan Fungsinya, Diakses pada 25 April 2015 , dari http://www.lutfichakim.com/2012/04/ mahasiswa-serta-peran-danfungsinya.html

Creswell, J. W. (2013). Research Design Pendekatan Kualitatif, Kuantitatif, dan Mixed, Yogyakarta: Pustaka Pelajar.

Fakultas Psikologi Universitas Islam Negeri Sunan Gunung Djati Bandung. (2012). Panduan Penyusunan dan Penulisan Skripsi, Tidak dipublikasikan.

Fakultas Psikologi Universitas Islam Negeri Sunan Gunung Djati Bandung. (2014). Panduan Penyusunan dan Penulisan Skripsi, Tidak dipublikasikan.

Hartono. (2011). Prediktor Skor Tes Kemampuan Berpikir Verbal, Numerikal, dan Abstrak terhadap Kriteria Prestasi Akademik Mahasiswa, Jurnal Penelitian Psikologi, 02(01), 112-121

Ling, J. \& Catling, J. (2012). Psikologi Kognitif, Jakarta : Penerbit Erlangga.

Republik Indonesia. (2003). Undangundang Republik Indonesia Nomor 20 Tahun 2003 tentang Sistem Pendidikan Nasional, Diakses pada 14 April 2016 dari http://kemenag.go.id/file/dokumen/UU 2003.pdf

Santoso, S. (2012). Aplikasi SPSS pada Statistik Parametrik, Jakarta: PT. Elex Media Komputindo.
Sho'imah, D. W. (2010). Hubungan Adversity Quotient dan Self Efficacy dengan Toleransi terhadap Stres pada Mahasiswa, Diakses pada 21 Agustus 2015

dari http://eprints.uns.ac.id/4210/1/1542221 08201011391.pdf

Silalahi, U. (2012). Metode Penelitian Sosial, Bandung: Refika Aditama.

Stoltz, P. G. (2000). Faktor Paling Penting dalam Meraih Sukses: Adversity Quotient Mengubah Hambatan Menjadi Peluang, Jakarta: Grasindo. (2005). Faktor Paling Penting dalam Meraih Sukses: Adversity Quotient Mengubah Hambatan Menjadi Peluang, Jakarta: Grasindo.

Sudjana. (2005). Metoda Statistika, Bandung: Tarsito

Supranto, J. (2008). Statistik Teori dan Aplikasi (Edisi Ketujuh), Jakarta: Penerbit Erlangga.

Syah, M. (2010). Psikologi Pendidikan dengan Pendekatan Baru (Edisi Revisi), Bandung: PT. Remaja Rosdakarya.

Yuniah. (2006). Faktor-Faktor yang Berpengaruh terhadap Prestasi Akademik Mahasiswa TPB IPB dengan Metode Chaid, Diakses pada 25 Maret 2016 dari http://repository.ipb.ac.id/handle/1234 $56789 / 46147$

Wade, C. \& Tavris, C. (2007). Psikologi (Edisi Kesembilan Jilid 2), Jakarta: Penerbit Erlangga. 